\title{
COLD SHORES IN WARMING TIMES - CURRENT STATE AND FUTURE CHALLENGES IN HIGH ARCTIC COASTAL GEOMORPHOLOGICAL STUDIES
}

\author{
Mateusz Czestaw StrZelecki \\ Adam Mickiewicz University in Poznań, Faculty of Geographical and Geological Sciences, Poland \\ \& Durham University, Department of Geography, Quaternary Environmental Change Group, UK
}

Manuscript received: June 24, 2011

Revised version: September 3, 2011

\begin{abstract}
StRZeleCKI M.C., Cold shores in warming times - current state and future challenges in High Arctic coastal geomorphological studie. Quaestiones Geographicae 30(3), Bogucki Wydawnictwo Naukowe, Poznań, pp. 101-113, 6 Figs. ISBN 978-83-62662-75-3. ISSN 0137-477X. DOI 10.2478/v10117-011-0030-0

АвSTRACT. Many of the existing intellectual paradigms regarding the functioning of the polar coastal zone are now out-dated, based on descriptive geomorphology and a limited process-based understanding. Currently, among many components of Arctic landscape adjusting to global warming, the coastal zone is probably the most critical one both in terms of rapidity of environmental change as well as importance for human communities living in circumpolar regions. This issue was often raised during the 4th International Polar Year 2007-2008 and encouraged the scientific community to focus on the state of cold region coasts in more detail. In this paper I summarize the most recent developments in Arctic coastal geomorphology with a particular focus on the Svalbard Archipelago and draw attention to the research challenges awaiting further investigation. This paper highlights the need for a greater understanding of the controls on High Arctic coastal geoecosystems, especially given the potential for accelerated warming and sea-level rise in the coming decades and centuries. Many of presented views benefited from discussions with Professor Andrzej Kostrzewski - to whom this volume is dedicated.
\end{abstract}

KEYWORDS: cold region coastal geomorphology, global warming, sea-level change, High Arctic landscape dynamics, Svalbard.

Matt Strzelecki, Durham University, Department of Geography, Science Site, South Road, Durham DH1 3LE, UK e-mail:mat.strzelecki@gmail.com

\section{The coasts of neglection}

Understanding the transition of Arctic regions, which in recent years have undergone a rapid environmental change in response to climate warming (Serreze et al. 2000; ACIA 2005; NorACIA 2011) is of crucial importance for the interpretation of Earth system reaction to former glaciations and climate shifts as well as more ac- curate prediction of future scenarios of global climate change. The tremendous research efforts undertaken during the $4^{\text {th }}$ International Polar Year 2007-2008 have revealed that the Arctic is already experiencing the strongest air and sea temperature rise on Earth. This process directly and indirectly changes the nature of the Arctic coastal zone. Of particular interest is the reaction of Arctic coastal geoecosystems to increased 


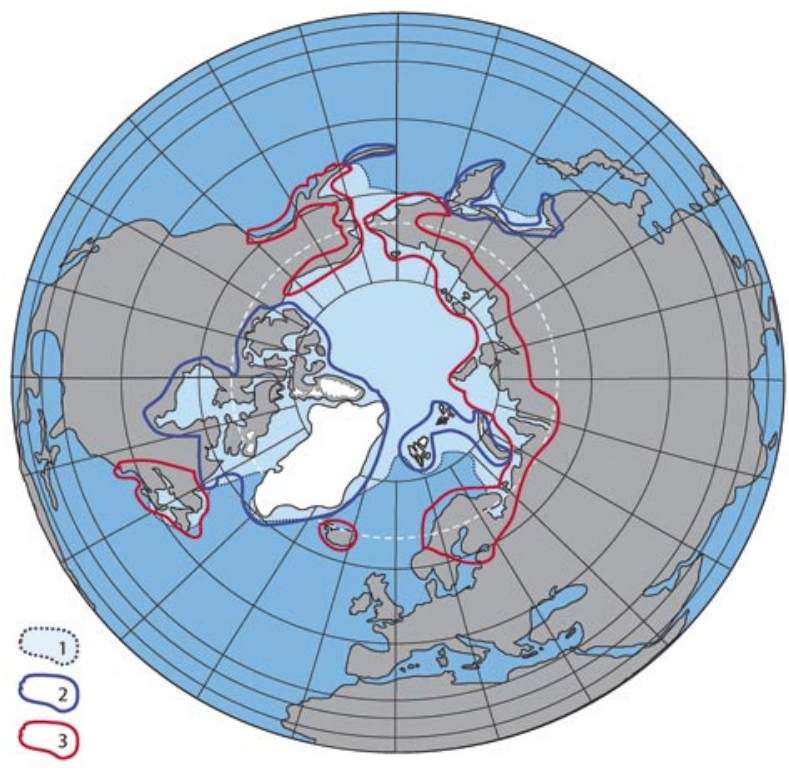

Fig.1. Simplified map of cold region coasts in the northern hemisphere (modified after Byrne \& Dionne 2002).

1 - Extent of winter sea ice cover; 2 - Zone of still relatively poorly studied cold region coasts where the mechanisms controlling coastal evolution remain unknown; 3 - Zone of relatively well-studied cold region coasts with running coastal erosion monitoring programmes, and number of high quality papers published in a last decade.

sediment and nutrient supply from land as well as increasing open-water conditions leading to intensified shoreline erosion and sediment transport. The recently published report 'The State of Arctic Coast 2010 Report' (Forbes et al. 2011) suggests that circumpolar coastal zone (Fig.1) is the key interface in the entire Arctic characterized by 'most rapid and severe environmental changes which have serious implications for communities living on coastal resources'. However, many of the existing opinions regarding the functioning of polar coasts based on limited observations are invalid and reduces our ability to understand current mechanisms controlling the present state of this fragile zone and do not deliver any sort of prediction of its future evolution. Not only is the number of academic papers on high latitude coastal environments lower than from temperate and tropical regions, but also their qualitative nature seems to be insufficient to allow numerical modelling and more sophisticated data analyses. In contrast to lower latitude coasts little is known regarding the potential impact of climate and sea-level change on high latitude coastal margins. This relative lack of research advance has persisted for several decades. This is highlighted by the remark from Trenhaile (1983) that there is a lack of even basic agreement on the efficiency of coastal processes in the high latitudes' then almost twenty years later Byrne \& Dionne (2002) reviewing the state of high latitude coastal geomorphology still had to admit that coastlines, accounting for at least $30 \%$ of the world coasts, have been neglected and studies on their nature are very limited. Most recently Lantuit et al. (2011) indicated that only $1 \%$ of Arctic coastlines have been investigated in sufficient detail to allow quantitative description of processes operating on them. One of the key messages found in all major papers reviewing the developments in cold region coastal studies is the need for long-term coastal change monitoring and selection of core geo-indicators which could be analyzed in a unified way under the umbrella of a circumpolar observation network (e.g. John \& Sugden 1975, Forbes \& Taylor 1994, Trenhaile 1997, Byrne \& Dionne 2002, Urdea 2007, Forbes et al. 2011). Though knowledge of the response of the coastal zone to climate change is fundamental to understanding polar landscape adjustment to global warming, we still cannot precisely measure the rate and scale of changes for vast areas of the Arctic. At the heart of the problem lies a mismatch between out-dated concepts based on short field observations and the lack of the studies linking Arctic coastal evolution with transformation of Arctic landscape occurring during climate shifts on millennial (glacials/interglacial), decadal (e.g. changes in atmospheric circulation patterns such as $\mathrm{NAO} / \mathrm{AO}$ ) and seasonal (i.e. the duration of snow cover, high/low precipitation, high/ low air temperatures, strong/weak winds etc.) timescales.

\section{‘Known knowns, known unknowns and unknown unknowns'}

Cold region coasts are typically defined as 'those areas where frost and ice processes are active during a period of the year which is sufficient to have a significant, if not permanent, impact on the near terrestrial, coastal and marine environments' (Byrne \& Dionne 2002). Several authors (e.g. Forbes \& Taylor 1994, Trenhaile 1997) noticed that many morphological aspects (cliffs, beaches, barriers, dunes, spits, embayments, lagoons) and 

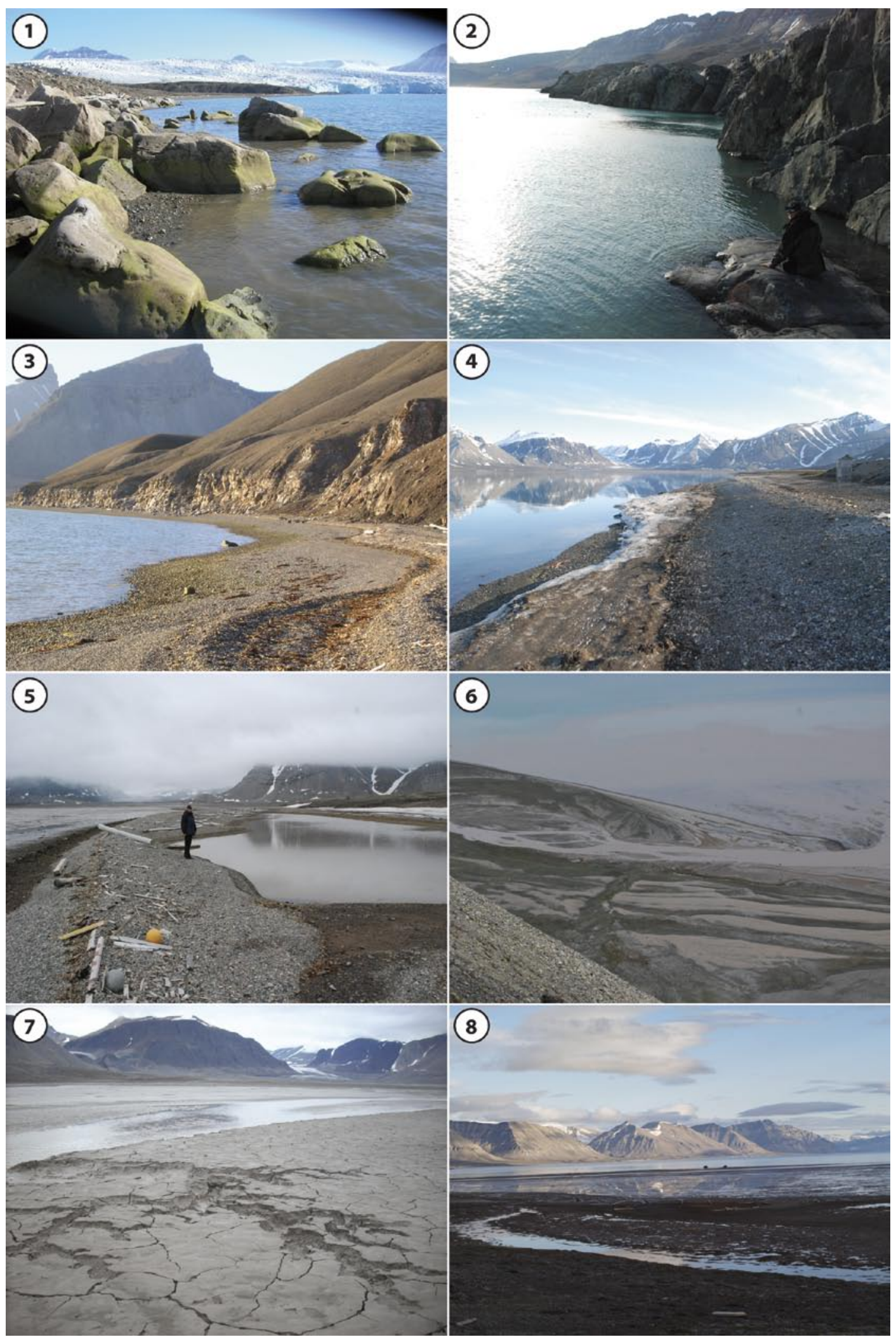

Fig. 2. High Arctic coastal environments in northern Billefjorden:

1 - sandstone boulder-strewn beach in northern Adolfbukta; 2 - plunging metamorphic rock cliffs in northern Adolfbukta; 3 - weathered rock cliffs and mixed sand-gravel barrier in eastern Petuniabukta; 4 - gravel barrier in eastern Petuniabukta; 5 - tidal flat (right), gravel spit (middle) and lagoon (left) in northern Petuniabukta; 6 - spit platform developing at the mouth of Ebbaelva (background), at the front uplifted beach sequences in NE Petuniabukta; 7 - tidal creek in central part of tidal flat (northern Petuniabukta); 8 - High Arctic salt marsh in NE Petuniabukta. 

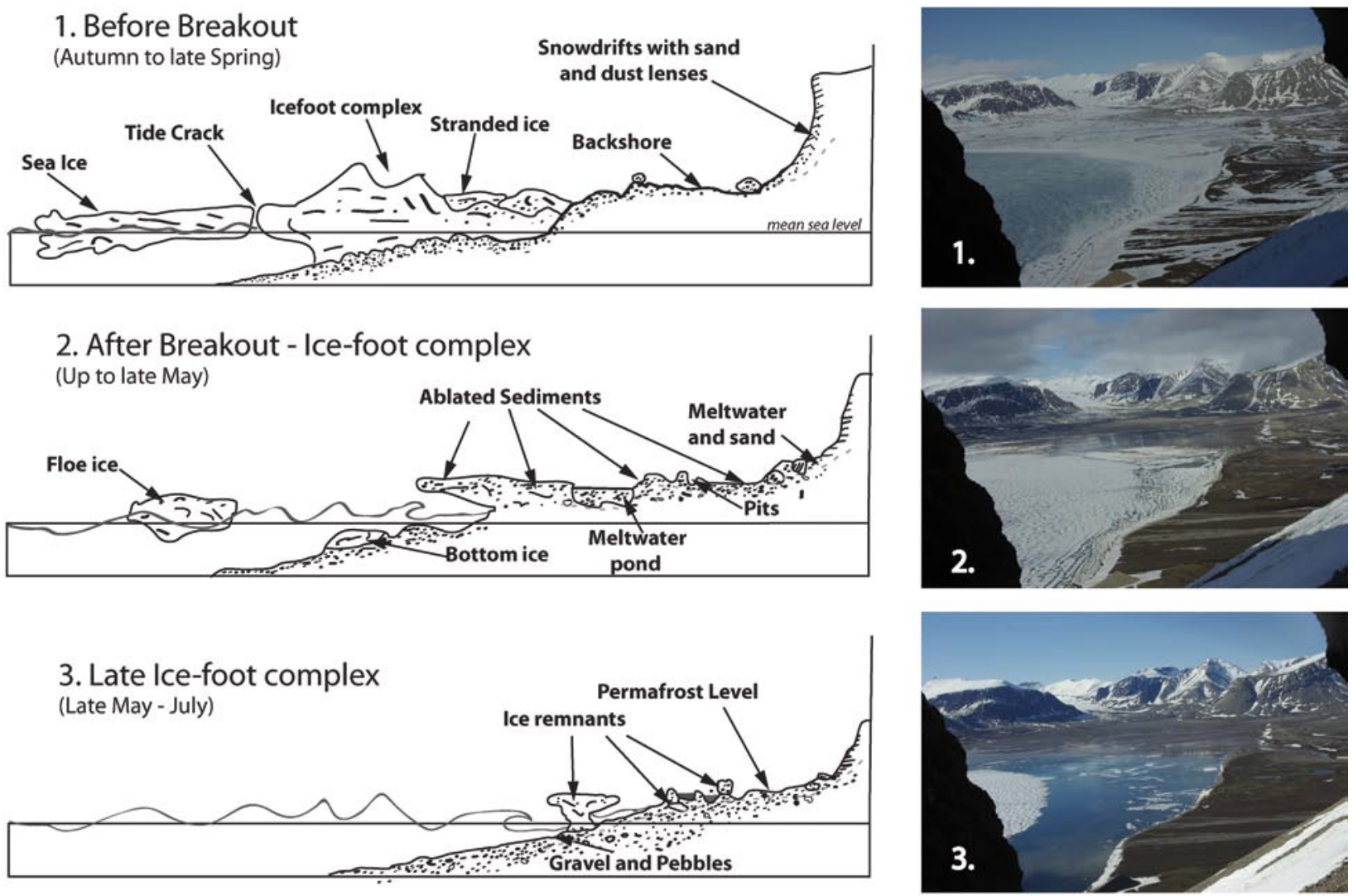

4. Full Beach

(mid-July to September)
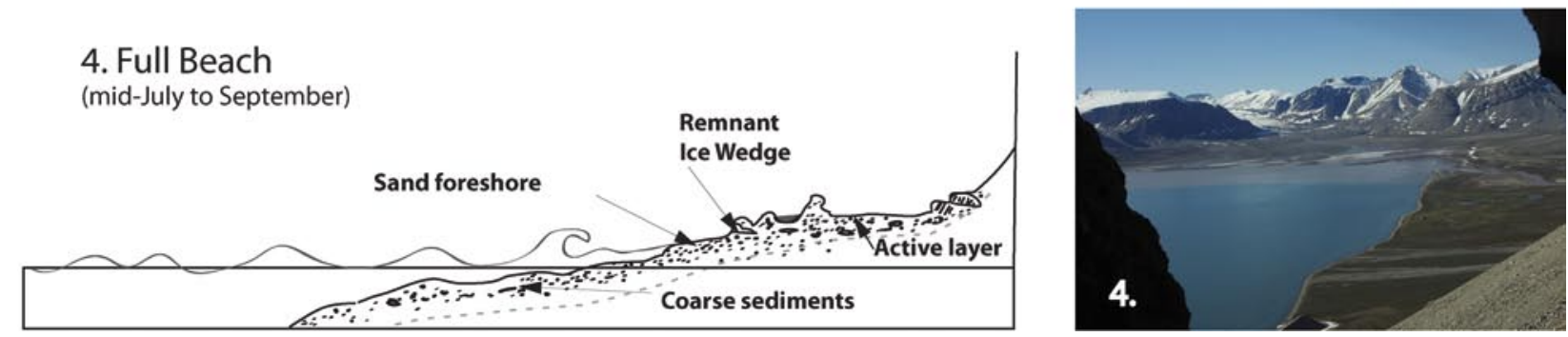

Fig. 3. Seasonal changes in polar beach profiles (sketches after Hansom and Kirk 1989) as they adjust to open water conditions. On the right examples of different stages of beach evolution from Petuniabukta (images taken by time-lapse camera installed on Wordiekammen massif in years 2009-2010)

processes (tides, currents, waves) operating on coasts in cold environments (Fig. 2) are similar to those from lower latitudes. What distinguishes them, however, are the effects of permafrost, ground ice, frost action, sea ice, snow cover, isostasy, glacial history and other zonal factors on coastal morphodynamics. It is important to notice that the scientific description of cold region coastal environments is characterized by many discrepancies. For instance, tremendous effort of Canadian researchers in last 40 years brought a major advance in our understanding of processes controlling Arctic tidal flats and development of the term glacielto describe ice-influenced landforms, sediments, processes in marine, coastal, estuarine, lacustrine and fluvial environments (e.g. Dionne 1968, 1969, 1988, 1989; Drake \& McCann 1982; McCann et al. 1981; McCann \& Dale 1986; Dale at al. 2002). Also Arctic beach environments (Fig. 3) have been solicitously described in many sites (e.g. Rex 1964; Hume \& Schalk 1964a, 1964b, 1967, 1976; Zenkovitch 1967; King \& Buckley 1968; McCann \& Owens 1969; Green 1970; Owens \& McCann 1970; McCann \& Taylor 1975; Rosen 1978; Taylor 1978; Reinson \& Rosen 1982; Sempels 1987; Reimnitz et al. 1990; Barnes et al. 1993, Campeau \& Héquette 1995) whereas to date there have been relatively few studies investigating Arctic rocky coasts (e.g. Jahn 1961; Nielsen 1979; Dionne \& Brodeur 1988, Fournier 
\& Allard 1992, Ødegård \& Sollid 1993; Ødegård et al. 1995; Lundberg \& Lauritzen 2002; Wagensteen et al. 2007; Strzelecki 2011). This gap is even more profound if we take into consideration that up to $35 \%$ of Arctic coastlines are rock-dominated (Lantuit et al. 2011). The classic example showing the research stagnation in revealing the complexity of high latitude rocky coastal zone is the longstanding controversy regarding the origin of strandflats. This has been a regular topic for discussion in the geomorphological literature for almost a century (Nansen 1922; Guilcher et al. 1986; Holtedahl 1998) and a debate on the efficiency of periglacial shoreline evolution, with enthusiasts of slow (Zenkovich 1967) and relatively rapid shore evolution (Jahn, 1961).

Furthermore, the development in Arctic coastal geomorphology is marked by significant regional contrast. The last decade has seen major developments in Arctic coastal research due to research from the Arctic Coastal Dynamics (ACD) Group (Rachold et al. 2005; Overduin et al. 2007; Lantuit \& Pollard 2008, Lantuit et al. 2011). Another important step was the reopening of Russian works to the wider scientific community, especially in the field of thermoabrasion and coasts formed in the Yedoma formation (e.g. Aré 1988; Nikiforov et al. 2005; Leontiev 2006; Aré et al. 2008; Lukyanova et al. 2008; Streletskaya et al. 2009). The major focus in these initiatives has been the understanding and modelling of ice-rich permafrost along Alaskan and Siberian coastlines. The study by Lantuit et al. (2011) indicated that in comparison to Beaufort and Laptev Sea coastlines, the coasts of High Arctic archipelagos such as Svalbard, Franz Josef Land, the Canadian Arctic Archipelago (CAA) and Greenland, whose melting ice masses contribute the most to present-day sea level rise, are still poorly recognized. Nevertheless, thanks to research projects carried out by ACD (Fig. 4) we can consider the beginning of the $21^{\text {st }}$ century as a golden decade of Arctic coastal studies. Their main findings and predictions from the perspective of coastal geomorphology are:

- the expected strong link between Arctic coastal evolution in coming decades and climate warming;

- the duration, intensity and number of storms entering the Arctic has already increased and the wave influence on the Arctic coasts will continue to intensify with implications for accelerated erosion;

- the changing Arctic sea-ice regime and the timing of ice break-up and freeze-up may result in further reduction of coastal protection from waves (in last decade sea-ice extent reached record minima in extent and perennial ice has been reduced by almost $50 \%$ in extent);

- the increased sea-surface temperatures, longer ice-free periods and intensified thawing of subsea, coastal and inland permafrost leads to rapid erosion and retreat of Arctic coasts as it was documented in recent years in Alaska and Siberia. ACD calculations of mean rates of coastal retreat in the last decades are typically in the 1-2 $\mathrm{m}$ /year range, but vary up to 10-30 m/year along the Beaufort Sea, the East Siberian Sea, and the Laptev Sea. ACD proved that previous reports underestimated the sediment and carbon supply from Arctic coasts to the ocean;

- the existence of a strong link between sea-level rise in the Arctic coastal zone and warming of the coastal waters as well as increased water freshening;

- the rise in sea level is expected to enhance coastal erosion and affect sediment transport in coastal areas (various IPCC models show higher sea-level rise in the Arctic than meanglobal rise);

- glacial legacy (glacioisostatic uplift/subsidence) is a dominant factor controlling the relative sea-level change and is characterized by strong regional contrasts e.g. Canadian Arctic Archipelago with emerging central part and submerging margins;

- climate warming leads to increased Arctic river discharge and sediment supply to the coastal zone. However, in some locations increased terrestrial sediment delivery is not sufficient to balance the negative changes caused by sea-level rise and storm flooding, what leads to submergence and erosion of Arctic deltas, e.g. the second largest Arctic delta, the Mackenzie Delta, is retreating dozens of meters per year.

Currently, the leaders of ACD are planning the organisation of the Arctic Circumpolar Coastal Observatory Network, which should cover more 


\section{A) PROCESSES ACTIVE ON ARCTIC PERMAFROST COASTS (e.g. SIBERIA) \\ environmental \\ forcing}

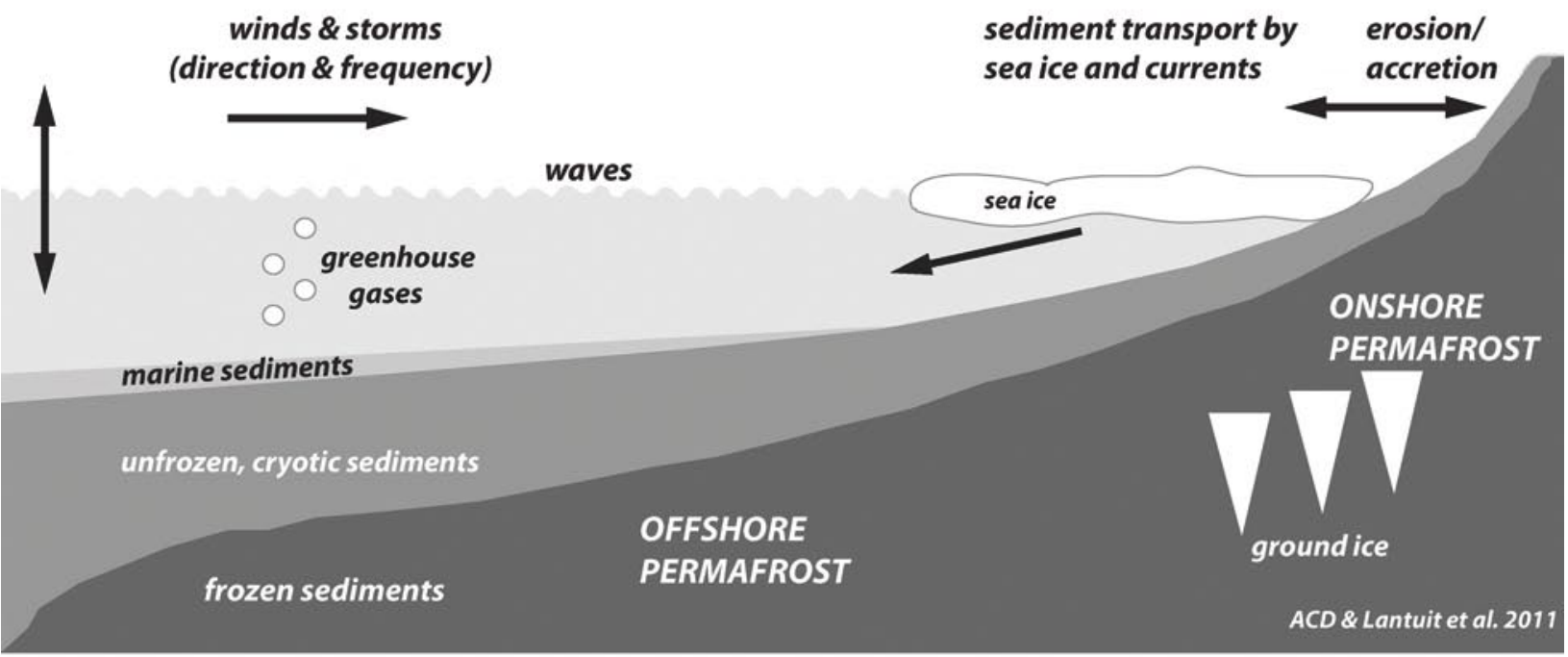

B) PROCESSES ACTIVE ON HIGH ARCTIC PARAGLACIAL COASTS (e.g. SVALBARD)

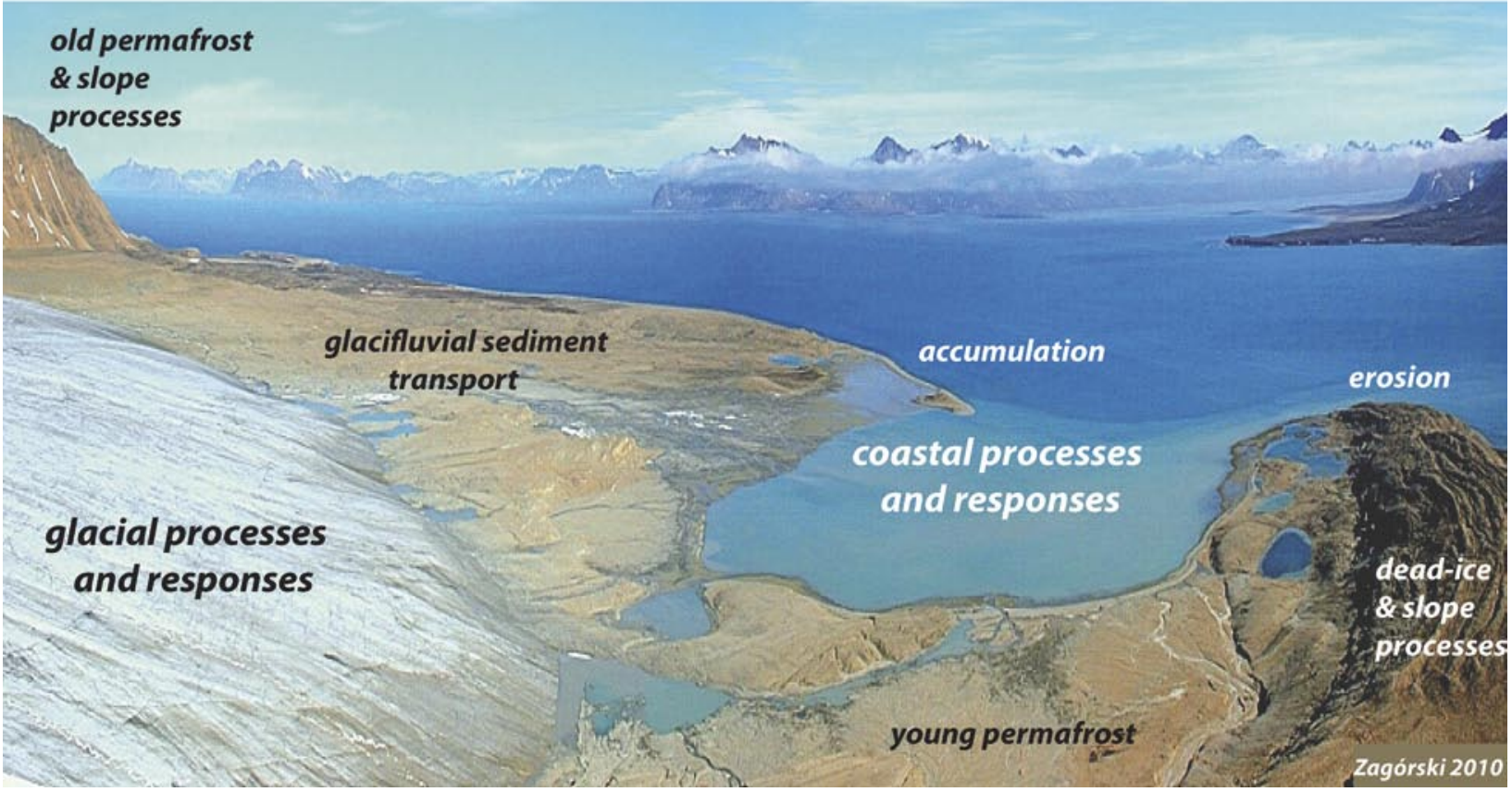

Fig. 4. Functioning of Arctic coastal zone:

A - model developed by Arctic Coastal Dynamics Group for ice-rich permafrost coasts characteristic for Siberian and Alaskan coasts (after Lantuit et al. 2011); B - the complexity of High Arctic coastal adjustment to glacier retreat - no model exists (Photo by Piotr Zagórski, 2010, illustrating paraglacial coastal system in Bellsund, Spitsbergen).

sites in the High Arctic and diametrically change the regional disproportion. It is then important to ask what kind of research challenges await the scientific community along the High Arctic coasts.

\section{High Arctic enigma}

To date coastal research in High Arctic settings has been strongly linked to the successful application of the paraglaciation concept (sensu 
Slaymaker, 2011) in cold region geomorphological studies. During the 1990s French geomorphologists dominated research on High Arctic paraglacial coastal systems. Their research focused on the response of the coastal zone to changes in glacial systems. Héquette \& Ruz (1990) and Héquette (1992) suggested that although High Arctic coasts are thought to be low energy in a certain conditions they can transform very rapidly. Their study on coastal margins of glaciofluvial outwash plains in northwest Spitsbergen (Brøgger Peninsula) documented a whole mosaic of abrupt changes in coastal morphology during the short Arctic summer with coexisting episodes of erosion and deposition, formation of new and cannibalization of old barriers, deposition of micro-deltas, landward and seaward migration of coastlines depended on rate of glaciofluvial activity in the surrounding and ability of storm waves to overwash barrier crests.

Mercier \& Laffly (2005) linked the periods of intensified sediment supply, associated with the post-Little Ice Age (LIA) retreat of Pedersenbreen, Austre, Midre and Vestre Lovénbreen with coastal progradation. During the last 30 years, the mean annual coastal progradation along studied section of Kongsfjorden was $3 \mathrm{~m}$. It has also been noted that in coastal sections where glaciofluvial sediment delivery was reduced shoreline recession was observed. This study demonstrated the high sensitivity of Svalbard coasts to mechanisms controlling the supply of sediments from deglaciated catchments. In this respect their work confirmed earlier observations from Atlantic Canada, made by Forbes and Taylor (1987) who recorded onshore migration of gravel barriers during periods of sediment shortage and spit extension after an increase in sediment input. In more sheltered area of Spitsbergen, centrally located - Petuniabukta, characterized by limited fetch and prolonged sea-ice conditions, Strzelecki (2011) reported similar rates of coastal adjustment. This research suggests that High Arctic coasts fed by paraglacially reworked and transported sediments deserve a new model, which will properly reflect the interplay between sediment supply, sea-level change and glacial landscape transition. This is important because many sections of the Svalbard coast are clearly still responding to a combination of ongoing paraglacial and coastal processes.
In recent decades paraglacial processes have became one of the most effective geomorphological processes on Svalbard, reducing the impact of glacial processes to a secondary role in landscape transformation (Laffly \& Mercier 2002, Rachlewicz 2010). Also the previous natural shoreline protection in the form of sea-ice, ice-foot complex and snow cover now disappear earlier and form later in the season allowing warmer and stormier sea conditions to access unconsolidated shorelines.

Based on several environmental monitoring case studies on Strokdammane Plain (W Spitsbergen) Åkerman (2008) proposed a geoecological model of Svalbard coasts under global warming conditions (Fig. 5). Åkerman predicts that prolonged duration of the open waters will be critical to the future impacts of coastal and near-coastal processes and environments in sites such as Svalbard. With frequent storms abrading unprotected shores additionally destabilized by thawing permafrost, flooding of coastal lowlands, high and wide barrier systems blocking stream outlets, Svalbard coastal geoecosystem will change rather abruptly.

On the other hand, Ziaja et al. (2009) already documented a whole cycle of coastal landscape transition related to the post-LIA deglaciation of Humbergbukta in SE Sorkapp which highlighted the role of changes in the High Arctic coastal zone as a simulator of polar life expansion. Retreat of Hambergbreen and other surrounding glaciers not only led to formation of new coastlines which quickly become transformed by coastal processes, but also exposed new areas for plant succession and animal colonization.

Another example of Svalbard coastal zone adjustment to climate warming and change in sediment delivery pathways was a study on the decadal-scale shoreline dynamics of Calypsostranda carried by Zagórski (2011). His investigations, combining remote sensing and field-based observations indicated the dominance of coastal erosion over accumulation with maximum coastal retreat up to $100 \mathrm{~m}$, regardless of the retreat of surrounding glaciers and increased sediment supply to the fjord system. In addition, based on a study of post-LIA geosuccession in Recherfjorden region Zagórski et al. (in preparation) developed a concept of direct and indirect glacial in- 


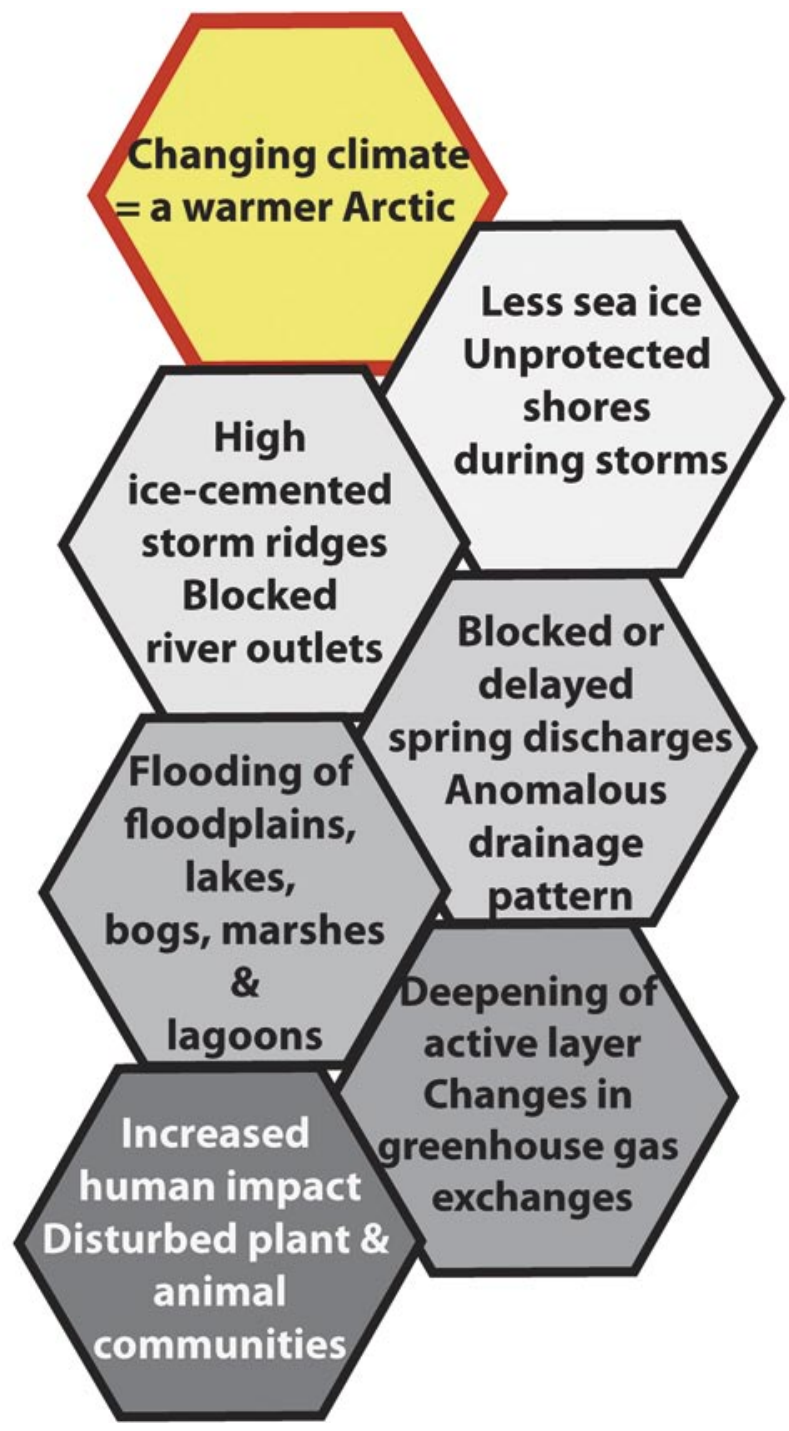

Fig. 5. Scenario of geoecological changes of Svalbard coasts under global warming conditions (modified after Åkerman 2008).

fluence on High Arctic coastal evolution which differentiates coasts formed after retreat of tidewater glaciers from coasts formed due to intensification of sediment delivery from valley-glacier systems. The direct influence of glacier systems on the coastal zone was previously documented by Nielsen (1992) in West Greenland. The retreat of the tide-water glacier Equip Sermia after the 1920s advance led to the transformation of a lateral moraine into a barrier spit and formation of a lagoon system in just 70 years. Nielsen argued that such a rapid landform transformation has serious implications for Holocene landscape interpretation, especially in case of landform and sediment assemblages related to tide-water glacier systems.
He also postulated a role of high waves induced by ice-berg roll from calving in over-washing and reshaping High Arctic coastal barriers, leading to the formation of boulder barricades and beaches. It has to be stated that the role of landslide (paraglacial) or ice-berg induced tsunami waves on the Arctic coastal morphology has never been studied in detail. Later on, Nielsen (1994) expanded his concept of glacier/coastal interaction during the study of Arctic delta in Sermilik Fjord. This is a key work documenting the sensitivity of the high latitude coastal zone to post-LIA landscape transition from glacier into paraglacial dominated geoecosystem and the rapidity with which such change can occur. During one century the delta system experienced all stages of evolution from rapid formation after retreat of Mitdluagkat glacier; progradation in response to intensified sediment supply; development of spits, barriers, tidal island and tombolos; finally to a degradation by waves and currents under rising sea-level conditions after reduction of delivery from glacier catchment. More recently Hansen (2004) illustrated the complexity of a High Arctic delta system response (Hall Bredning-Scoresby Sund, East Greenland) to change in topography, sediment supply, rate of deglaciation and shifts in climate on the Holocene timescale. Hansen's model can be adapted to hundreds of small and sheltered Arctic fjords deglaciated during the Holocene; it also proves that High Arctic coastal environments may serve as a useful tool in reconstructing environmental change.

\section{Stories to be rewritten}

One of the classic examples of the application of sedimentological survey of coastal landforms in palaeogeographical reconstruction is a study by Lønne \& Nemec (2004) on High Arctic coastal fan delta in Advenfjorden (Spitsbergen). By detailed sedimentological analysis of fan depositional structures they demonstrated the importance of fan deltas as a proxy record of deglaciation history and environmental change in a High Arctic terrain, especially important in regions characterized by low preservation of glacigenic sediments and landforms. The small fan system developing at the foot of Hiorthfjellet was a very precise re- 
corder of the interplay between terrestrial and marine processes adjusting to shifts in sediment delivery from retreating glacier as well as fluctuations of a sea-level. This study, apart from documenting in an unprecedented detail the sedimentology of a polar fan system fed by glacier streams, snow melt and degrading permafrost, also provided the first well-dated onshore proof for a Mid-Holocene transgression in central Spitsbergen. Surprisingly, even after this important research, the significance of cold region coastal fan systems still remains unrecognized.

Another important story can be added to reconstruction of polar landscapes by studying the sedimentology of gravel-dominated storm ridges preserved in many uplifted marine sequences across High Arctic region. In Andréeland (NW Spitsbergen) Brückner et al. (2002) and Brückner \& Schellmann (2003) postulated that uplifted beach ridges may help us decipher the glacio-isostatic and palaeoceanographic changes. They based their hypothesis on the assumption that conditions favourable for formation of beach ridges reflects existence of ice-free conditions associated with retreat of glacier systems and openwater summer season with wave and current activity. In the case of Woodfjorden and Wijdefjorden, formation of hundreds of Holocene beach ridges was possible only due to climate warming which lead to retreat of the glacier, opening of the fjord and entrance of warm waters brought by the West Spitsbergen Current securing removal of sea ice and open water conditions in summer months. More recently St-Hilaire-Gravel et al. (2010) studied the topography and sedimentology of uplifted beach ridges on Lowther Island (CAA) in order to test their ability to record past wave intensity and sea-ice conditions. However, reflecting only local conditions they suggested that better-developed beach ridges can be associated with periods of prolonged wave activity (increased duration of ice free periods). One future direction of research might be to compare the onshore record (beach ridges, coastal fan deltas) with the offshore record from ocean cores collected across the High Arctic to shed new light on the history of sea ice and ocean currents.

\section{Action instead of conclusions}

I strongly believe that the described gap in understanding of High Arctic coastal adjustment to global warming conditions represents a great opportunity for the national polar research community. Longstanding history of Polish investigations on Svalbard with environmental monitoring programmes running for decades as well as a network of research stations spread across Spitsbergen constitute a solid basis for an interdisciplinary research project focusing on the functioning of the coastal zone in the heart of the European Arctic. Due to its location at the boundary between oceanic and atmospheric fronts, Svalbard is one of the key areas to study the Arctic sensitivity to climate change. The Svalbard region has, therefore, been an area of many scientific breakthroughs including: palaeo-climate reconstructions (e.g. Isaksson et al. 2005); the extent of the last glaciation (e.g. Mangerud et al. 1998; Svendsen et al. 2004); Holocene sea level changes (e.g. Forman et al. 2004); modern and relict glacial systems (e.g. Boulton 1972; Lønne \& Lyså 2005; Nuth et al. 2010); periglacial permafrost processes and mechanisms (e.g. Humlum et al., 2003); ocean water interaction and mixing (e.g. ŚlubowskaWoldengen et al. 2007, Majewski et al. 2009). Despite the wealth of research which has been undertaken in Svalbard, there remains a lack of investigation into coastal processes and environments. Previous coastal studies (Mercier \& Laffly 2005, Ziaja et al. 2009, Strzelecki 2011, Zagórski 2011) document dramatic changes in sediment flux and coastal response under intervals characterised by a warming climate, retreating local ice masses, a shortened winter sea-ice season and melting permafrost. These terrestrial processes are interacting with glacio-isostatic land emergence and on-going global sea-level rise. The pristine coasts of Svalbard provide a superb opportunity to quantify how High Arctic coasts are responding to rapid climate warming. Nevertheless several crucial research questions are still to be answered including: What processes control existing Svalbard coasts?; How sensitive is the Svalbard coastal zone to recent increased human impact?; 
What was the response of the Svalbard coastal zone to intensified glacial recession and sediment supply after the Little Ice Age?; Do coastal processes intensify the rate of rock weathering on Svalbard climates?; How did the Svalbard coast and continental shelf respond to climate change, glacier fluctuations and sea ice changes throughout the Holocene?; What is the precision of the morphological and sedimentological records of environmental transformations, climate change and natural disasters along the Svalbard coast?

These research premises and challenges led to the formation of a SVALCOAST research team linking geoscientists from leading national polar research institutions and international scientific partners which in coming years will aim to examine the response of the coastal zone of the Svalbard Archipelago to current climatic warming and multidirectional anthropopression and explore the changes experienced by the coastal landscape during various stages of deglaciation. As well as this, predictions will be made as to the coast's future evolution under scenarios of continuing increases in air temperature and sealevel rise (Strzelecki \& Zagórski 2011). Given the diversity of research questions and rapidity of coastal adjustment it seems to be a fascinating challenge!

\section{Acknowledgements}

I would like to thank Professor Andrzej Kostrzewski for many years of excellent supervision,

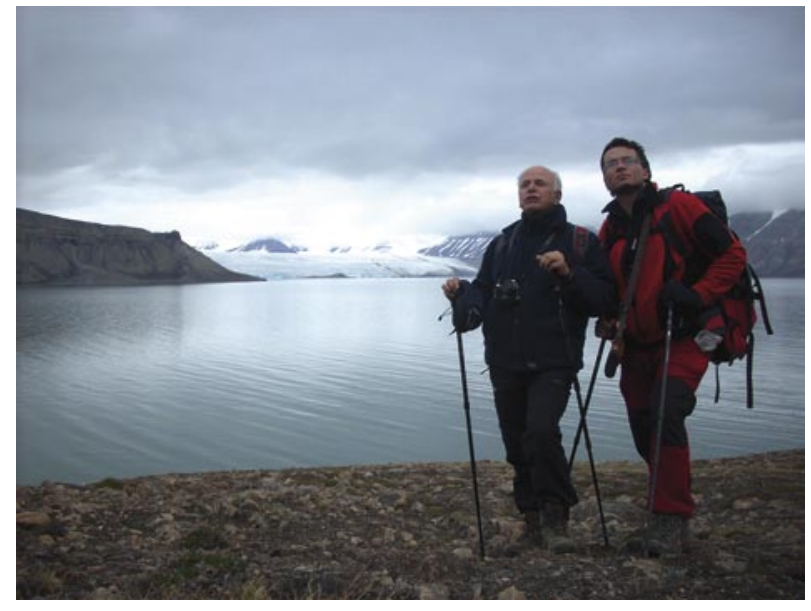

Fig. 6. Prof. Andrzej Kostrzewski and Matt Strzelecki during geomorphological mapping of western coast of Petuniabukta, Spitsbergen August 2007. friendship and helping me aim only for the highest goals.

Gratitiude is directed to Crescendum Est- Polonia Foundation, Adam Mickiewicz University Foundation, Ministry of Science and Higher Education in Poland (grant no. N306284335), National Environmental Research Council in UK and Ustinov College at Durham University supporting my research and career development.

I also thank Jerry Lloyd who gave critical comments on an earlier version of the manuscript. Review by Wiesław Ziaja also improved the manuscript and is highly appreciated.

\section{References}

ÅKerman J.H., 2008. Coastal Processes and Their Influence Upon Discharge Characteristics of the Strokdammane Plain, West Spitsbergen, Svalbard. Proceedings of the Ninth International Conference on Permafrost University of Alaska Fairbanks June 29-July 3, 2008 1: 19-24.

Arctic Climate Impact Assessment (ACIA) ScientificReport, 2005. Cambridge University Press, Cambridge.

Aré F.E., 1988. Thermal abrasion of sea coasts. Polar Geography and Geology 12: 1-157.

Aré F.E., Reimnitz E., Grigoriev M., Hubberten H.-W., RaCHOLD V., 2008. The influence of cryogenic processes on the erosional Arctic shoreface. Journal of Coastal Research 24: $110-121$.

Barnes P.W., Kempena E.W., Reimnitz E., Mccormick M., WeBER W.S. \& HAYDEN E.C., 1993. Beach profile modification and sediment transport by ice: an overlooked process on Lake Michigan. Journal of Coastal Research 9: 65-86.

Boulton G.S., 1972. Modern Arctic glaciers as depositional models for former ice sheets. Journal of Geological Society London 128: 361-393.

BrÜCKNER H. \& SChellmann G., 2003. Late Pleistocene and Holocene shorelines of Andréeland, Spitsbergen (Svalbard) - eomorphological evidence and palaeo-oceanographic significance. Journal of Coastal Research 19: 971982.

BRÜCKNer H., SChellmann G. \& van Der Borg K., 2002. Uplifted beach ridges in northern Spitsbergen as indicators for glacio-isostasy and palaeo-oceanography. Zeitschrift für Geomorphologie 46: 309-336.

Byrne M.-L. \& Dionne J.-C., 2002. Typical Aspects of Cold regions Shorelines. In: K. Hewitt, M.-L. Byrne, M. English, G. Young (eds.), Landscapes in Transition. Landform Assembladges and Transformations in Cold Regions. Kluver Academic Publishers, Dordrecht: 141-158.

CAmpeau S. \& Héquette A., 1995. Buttes cryogènes saisonnières de plages arctiques, péninsule de Tuktoyaktuk, Territoires du Nord-Ouest. Géographie physique et Quaternaire 49: 265-274.

Dale J.E., Leech S., McCann B. \& Samuelson G., 2002. Sedimentary characteristics, biological zonation and physical processes of the tidal flats of Iqaluit, Nunavut. In: K. Hewitt, M.-L. Byrne, M. English, G. Young (eds.), Landscapes in Transition. Landform Assembladges and Transfor- 
mations in Cold Regions. Kluver Academic Publishers, Dordrecht: 205-234.

Dionne J.-C., 1968. Morphologie et sedimentologie glacielles, littoral sus du Saint-Laurent. Zeitschrift fur Geomorphologi, Supplement Band 7: 56-84.

Dionne J.-C., 1969. Tidal flat erosion by ice at La Pocatière, St. Lawrence Estuary. Journal of Sedimentary Petrology 39: 1174-1181.

DiONNE J.-C., 1988. Characteristic features of modem tidal flats in cold regions. In: P.L. de Boer et al. (eds.), Tide influenced sedimentary environments and facies. Dordrecht: 301-332.

DionNE J.-C., 1989. The role of ice and frost in tidal marsh development. A review with particular reference to Quebec, Canada. Earth Science Reviews 26: 185-212.

Dionne J.-C. \& BRodeur D., 1988. Frost weathering and ice action in shore platform development, with particular reference to Quebec, Canada. Zeitschrift fur Geomorphologie, Supplement Band 71: 117-130.

DRAKE J.J. \& McCANN S.B., 1982. The movement of isolated boulders on tidal flats by ice floes. Canadian Journal of Earth Sciences 19: 748-54

Forbes D.L. (ed.), 2011. State of the Arctic Coast 2010 - Scientific Review and Outlook. International Arctic Science Committee, Land-Ocean Interactions in the Coastal Zone, Arctic Monitoring and Assessment Programme, International Permafrost Association. Helmholtz-Zentrum, Geesthacht, Germany (http:/ / arcticcoasts.org).

ForBES D.L. \& TAYLOR R.B., 1987. Coarse-grained beach sedimentation under paraglacial conditions, Canadian Atlantic Coast. In: D. Fitzgerald, P. Rosen (eds.), Glaciated Coasts. Academic Press, New York: 51-86.

Forbes D.L. \& TAYLor R.B., 1994. Ice in the shore zone and the geomorphology of cold coasts. Progress in Physical Geography 18: 59-89.

Forman S., Lubinski D., Ingolfsson O., Zeeberg J., SNYder J., SiEgert M. \& Matishov G., 2004. A review of postglacial emergence on Svalbard, Franz Josef Land and Novaya Zemlya, northern Eurasia. Quaternary Science Reviews 23: 1391-1434.

FouRnier A. \& AlLARD M., 1992. Periglacial shoreline erosion of rocky coast: George River Estuary, Northern Quebec. Journal of Coastal Research 8: 926-942.

GREENE H.G., 1970. Microrelief on an arctic beach. Journal of Sedimentary Petrology 40: 419-427.

Guilcher A., Bodere J.-C., Coude A., Hansom J.D., Moign A. \& Peulvast J.-P., 1986. The Strandflat problem in Five High Latitude Countries. In: D.J. Evans (ed.), Cold Climate Landforms. Wiley, Chichester: 351-393.

Hansen L., 2004. Deltaic infill of a deglaciated Arctic fjord, East Greenland: Sedimentary facies and sequence stratigraphy. Journal of Sedimentary Research 74: 422-437.

HANSOM J.D. \& KIRK R.M., 1989. Ice in the intertidal zone: examples from Antarctica. In: E.C.F. Bird, D. Kelletat (eds.), Zonality of Coastal Geomorphology and Ecology. Essener Geographische Arbeiten 18: 211-236.

Héquette A. 1992. Morphosedimentological dynamics and coastal evolution in the Kongsfjorden area, Spitsbergen. Polar Geography and Geology 16: 321-329.

Héquette A. \& Ruz M.-H., 1990. Coastal sedimentation along glacial outwash plain shorelines in northwest Spitsbergen. Géographie physique et Quaternaire 44: 77-88.

Holtedal H., 1998. The Norwegian strandflat - a geomorphic puzzle. Norsk Geologisk Tidsskrift 78: 47-66.
Hume J.D. \& SCHALK M., 1964a. The effects of beach barrow in the Arctic. Shore and Beach 32: 37-41.

Hume J.D. \& SchalK M., 1964b. The effects of ice-push on Arctic beaches. American Journal of Science 262: 267-273.

Hume J.D. \& Schalk M., 1967. Shorline processes near Barrow, Alaska: a comparison of the normal and the catastrophic. Arctic 20: 86-103.

Hume J.D. \& SCHALK M., 1976. The effects of ice on the beach and nearshore, Pt Barrow, Arctic Alaska. La Revue de Geographie de Montreal 30: 105-114.

Humlum O., Instanes A. \& Sollid J.L., 2003. Permafrost in Svalbard: a review of research history, climatic background and engineering challenges. Polar Research 22: 191-215.

Isaksson E., Divine D., Kohler J., Martma T., Pohjola V., Motoyama H. \& Watanabe O., 2005. Climate oscillations as recorded in Svalbard ice core $\delta 180$ records between ad 1200 and 1997. Geografiska Annaler 87 A: 203-214.

JAHN A., 1961. Quantitative analysis of some periglacial processes in Spitsbergen. Zeszyty Naukowe Uniwersytetu Wroctawskiego, seria B, 5, Nauka o Ziemi II/Geophysics, Geography, Geology II: 3-54.

John B.S. \& Sugden D.E., 1975. Coastal geomorphology of high latitudes. Progress in Geography 7: 53-132.

KING C.A.M. \& BucKLEY J.T., 1968. The analysis of stone size and shape in an Arctic environment. Journal of Sedimentary Petrology 38: 200-218.

Laffly D. \& Mercier D., 2002. Global change and paraglacial morphodynamic modification in Svalbard. International Journal of Remote Sensing 43: 4743-4760.

Lantuit H., Overduin P.P., Couture N., Aré F., Atkinson D., Brown J., Cherkashov G., Drozdov D., Forbes D.L., Graves-Gaylord A., Grigoriev M., Hubberten H.-W., JorDAN J., JoRgENSON T., ØDEGÅRd R.S., Ogorodov S., Pollard W., Rachold V., Sedenko S., Solomon S., Steenhuisen F., Streletskaya I., Vasiliev A. \& Wetterich S., 2011. The ACD coastal database: a new classification scheme and statistics on Arctic permafrost coastlines. Estuaries and Coasts (Online: DOI: 10.1007/s12237-010-9362-6).

Lantuit H. \& Pollard W.H., 2008. Fifty years of coastal erosion and retrogressive thaw slump activity on Herschel Island, southern Beaufort Sea, Yukon Territory, Canada. Geomorphology 95: 84-102.

Lantuit H., Rachold V., Pollard W.H., Steenhuisen F., ØDegÅRD R. \& HubBerten H.-W., 2009. Towards a calculation of organic carbon release from erosion of Arctic coasts using non-fractal coastline datasets. Marine Geology 257: 1-10.

LeONTIEV I.O., 2006. Forecast of Coastal Changes Based on Morphodynamical Modeling. Oceanology 46: 564-572.

LøNNE I. \& LYSÅ A., 2005. Deglaciation dynamics following the Little Ice Age on Svalbard: Implications for shaping of landscapes at high latitudes. Geomorphology 72: 300-319.

LøNNE I. \& Nemec W., 2004. High-arctic fan delta recording deglaciation and environment disequilibrium. Sedimentology 51: 553-589.

Lukyanova S.A., Safyanov G.A., Soloveva G.D. \& Shipilova L.M., 2008. Types of Arctic Coasts of Russia. Oceanology 48: 268-274.

LundBerg J. \& Lauritzen S.-E., 2002. The search for an Arctic coastal karren model in Norway and Spitzbergen. In: K. Hewitt, M.-L. Byrne, M. English, G. Young (eds.), Landscapes in Transition. Landform Assembladges and Transformations in Cold Regions. Kluver Academic Publishers, Dordrecht: 185-203. 
MajeWSKi W., Szczuciński W. \& ZajĄczKowski M., 2009. Interactions of Arctic and Atlantic water-masses and associated environmental changes during the last millennium, Hornsund (SW Svalbard). Boreas 38: 529-544.

Mangerud J., Dokken T., Hebbeln D., Heggen B., Ingolfsson O., Landvik J.Y., Mejdahl V., Svendsen J.I. \& Vorren T.O., 1998. Fluctuations of the Svalbard-Barents Sea ice sheet during the last 150000 years. Quaternary Science Reviews 17: $11-42$.

McCANn S.B. \& DALE J.E., 1986. Sea ice breakup and tidal flat processes, Forbisher Bay, Baffin Island. Physical Geography 7: 168-180.

McCann S.B., Dale J.E. \& Hale P.B., 1981. Subarctic tidal flats in areas of large tidal range, southern Baffin Island, Eastern Canada. Géographie physique et Quaternaire 35: 183-204.

McCANN S.B. \& OwEns E.H., 1969. The size and shape of sediments in three Arctic beaches, SW Devon Island, NWT. Arctic and Alpine Research 1: 267-278.

McCANN S.B. \& TAYLOR R.B., 1975. Beach freezeup sequence at Radstock Bay, Devon Island, Arctic Canada. Arctic and Alpine Research 7: 379-386.

Mercier D., 2008. Paraglacial and paraperiglacial landsystems: concepts, temporal scales and spatial distribution. Géomorphologie: relief, processus, environnement 4: 223-233.

Mercier D., Étienne S., Sellier D. \& André M.-F., 2009. Paraglacial gullying of sediment-mantled slopes: a case study of Colletthøgda, Kongsfjorden area, West Spitsbergen (Svalbard). Earth Surface Processes and Landforms 34: 1772-1789.

MerCier D. \& LAfFly D., 2005. Actual paraglacial progradation of the coastal zone in the Kongsfjorden area, western Spitsbergen (Svalbard). In: C. Harris, J.B. Murton (eds.), Cryospheric systems: glaciers and permafrost. Geological Society, London: 111-117.

NANSEN F., 1922. The strandflat and isostasy. Videmkapsselskapets Skrifier. I. Mat.-Naturu. Klasse. 192111.

Nichols R.L., 1961. Characteristics of beaches formed in polar climates. American Journal of Science 259: 694-708.

Nielsen N., 1979. Ice-foot processes. Observations of erosion of the rocky coast, Disko, West Greenland. Zeitschrift für Geomorphologie 23: 321-331.

Nielsen N., 1992. A boulder beach formed by waves from a calving glacier: Eqip Sermia, West Greenland. Boreas 21: 159-168.

Nielsen N., 1994. Geomorphology of a Degrading Arctic Delta, Sermilik, South-East Greenland. Geografisk Tidsskrift 94: 46-57.

Nikiforov S., Pavlidis Y., Rachold V., Grigoryev M., RivkiN M, Ivanova N. \& Koreisha M., 2005. Morphogenetic classification of the Arctic coastal zone. Geo-Marine Letters 25: 89-97.

Norwegian Arctic Climate Impact Assessment (NorACIA) Report 2011. Climate change in the Norwegian Arctic. Consequences for life in the north. Norwegian Polar Institute Raport Series 136.

Nuth C., Moholdt G., Kohler J., Hagen J.O. \& KäÄв A., 2010. Svalbard glacier elevation changes and contribution to sea level rise. Journal of Geophysical Research 115: doi:10.1029/2008JF001223.

Overduin P.P., Hubberten H.-W., Rachold V., Romanovskil N., Grigoriev M.N. \& Kasymskaya M., 2007. Evolution and degradation of coastal and offshore permafrost in the Laptev and East Siberian Seas during the last climatic cycle, Coastline changes: interrelation of climate and geological processes. In: J. Harff, W.H. Hay, D.M. Tetzlaff (eds.), The Geological Society of America special paper 426, Boulder, Colorado: Geological Society of America, 97-111. doi:10.1130/2007.2426(07).

Owens E.H. \& McCanN S.B., 1970. The role of ice in the arctic beach environment with special references to Cape Ricketts, south-west Devon Island, Northwest Territories, Canada. American Journal of Science 268: 397-414.

Ødegård R.S., Etzelmüller B., Vatne G. \& Sollid J., 1995. Nearsurface spring temperatures in an Arctic coastal cliff: possible implications of rock breakdown. In: $\mathrm{O}$. Slaymaker (ed.), Steepland geomorphology. Wiley, Chichester: 89-102.

ØDEGÅRD R.S. \& SolLID J.L., 1993. Coastal cliff temperatures related to the potential for cryogenic weathering processes, western Spitsbergen, Svalbard. Polar Research 12: 95-106.

RACHLEWICZ G., 2010. Paraglacial modifications of glacial sediments over millennial to decadal time-scales in the high Arctic (Billefjorden, central Spitsbergen, Svalbard). Quaestiones Geographicae 29: 59-67.

Rachold V., Are F., AtKinson D., Cherkashov G. \& Solomon S., 2005. Arctic Coastal Dynamics (ACD): an introduction. Geo-Marine Letters 25: 63-68.

Reimnitz E., Barnes P.W. \& Harper J.R., 1990. A review of beach nourishment from ice transport of shoreface materials, Beaufort Sea, Alaska. Journal of Coastal Research 6: 439-470.

Reinson G.E. \& Rosen P.S., 1982. Preservation of ice-formed features in a sub-Arctic sandy beach sequence: geologic implications. Journal of Sedimentary Petrology 52: 463-471.

Rex R.W., 1964. Arctic Beaches, Barrow, Alaska. In: R.L. MitLER (ed.), Papers in Marine Geology. MacMillan, New York: 384-400.

Romanovski N., Hubberten H.-W., Gavrilov A., Tumskoy V. \& KHOLOdov A.L., 2004. Permafrost of the east Siberian Arctic shelf and coastal lowlands. Quaternary Science Reviews 23: 1359-1369.

Rosen P.S., 1978. Degradation of ice-formed beach deposits. Maritime Sediments 14: 63-68.

SEmPels J.M., 1987. The Coastal Morphology and Sedimentology of Cape Hatt Peninsula. Arctic 40: 10-19.

Serreze M., Welsh J., Chapin III F., Osterkamp T., Dyurgerov M., Romanowvsky V., Oechel W., Morison J., Zhang T. \& BARRY R., 2000. Observational evidence of recent change in the northern high-latitude environment. Climatic Change 46: 159-207.

SlaymaKer O., 2011. Criteria to distinguish between periglacial, proglacial and paraglacial environments. Quaestiones Geographicae 30: 85-94.

SoLOMON S.M., 2005. Spatial and temporal variability of shoreline change in the Beaufort-Mackenzie region, northwest territories, Canada. Geo-Marine Letters 25: 127-137.

St-Hilaire-Gravel D., Bell T. \& Forbes D., 2010. Raised Gravel Beaches as Proxy Indicators of Past Sea-ice and Wave Conditions, Lowther Island, Canadian Arctic Archipelago. Arctic 63: 213-226.

Streletskaya I.D., Vasiliev A.A. \& VAnstein B.G., 2009. Erosion of sediment and organic carbon from the Kara Sea coast. Arctic, Antarctic, and Alpine Research 41: 79-87.

StRZELECKI M.C., 2011. Paraglacial processes operating on High Arctic coastal margins - recent advances from Svalbard. Geophysical Research Abstracts 13: EGU2011-871, 2011. 
StRZELECKI M.C., 2011. Schmidt hammer tests across recently deglacierized rocky coastal zone - is there a 'coastal amplification' of rock weathering in polar climates? Polish Polar Research 32 (in press).

StRZeleCKi M.C. \& ZAGÓRSKi P., 2011. SVALCOAST Project background, aims, impact plan. SVALCOAST Group meeting, Sosnowiec.

Svendsen J.A., Alexanderson H., Astakhov V.I., Demidov I., Dowdeswell J.A., Funder S., Gataullin V., Henriksen M., HJort C., Houmark-Nielsen M., Hubberten H.W., InGÓlfsson O., Jakobsson M., KJer K.H., Larsen E., Lokrantz H., LunKKa J.P., LysÅ A., MANGerud J., MatiouchKov A., Murray A., Möller P., Niessen F., Nikolskaya O., Polyak L., SaArnisto M., Siegert C., Siegert M.J., Spielhagen R.F. \& STEIN R., 2004. Late Quaternary ice sheet history of northern Eurasia. Quaternary Science Reviews 23: 1229-1271.

ŚlubowsKa-Woldengen M., Rasmussen T.L., Koç N., KlitgaArd-Kristensen D., Nilsen F. \& Solheim A., 2007. Advection of Atlantic Water to the western and northern Svalbard shelf since 17,500 cal yr BP. Quaternary Science Reviews 26: 463-478.

TAYLOR R.B., 1978. The occurrence of grounded ice ridges and shore ice piling along the northern coast of Somerset Island, N.W.T. Arctic 31: 133-139.
Trenhaile A.S., 1983. The development of shore platforms in high latitudes. In: D.E. Smith, A.G. Dawson (eds.), Shorelines and Isostasy. Institute of British Geographers, Special Publication 16, London: 77-96.

Trenhaile A.S., 1997. Coastal Dynamics and Landforms. Oxford University Press, Oxford.

URDEA P., 2007. About some geomorphological aspects of the polar beaches. Revista de geomorfologie 9: 5-16.

WANGensteen B., EIKen T., ØDEGÅRD R.S., SOlLid J.L. \& 2007. Measuring coastal cliff retreat in the Kongsfjorden area, Svalbard, using terrestrial photogrammetry. Polar Research 26: 14-21.

ZAGÓRSKI P., 2011. Shoreline dynamics of Calypsostranda (NW Wedel Jarlsberg Land, Svalbard) during the last century. Polish Polar Research 32: 67-99.

Zagórski P., Gajek G. \& Demczuk P., in prep. The influence of glacier systems of polar catchments on functioning of the coastal zone (Recherchefjorden, Svalbard). Submitted to Zeitschrift für Geomorfologie.

ZenKovich V.P., 1967. Processes of Coastal Development. Trans. O.G. Fry, J.A. Steers. Oliver and Boyd, Edinburgh.

Ziaja W., Maciejowski P. \& Ostafin K., 2009. Coastal Landscape Dynamics in NE Sørkapp Land (SE Spitsbergen), 1900-2005. Ambio 38: 201-208. 